San Jose State University

SJSU ScholarWorks

Master's Theses

Master's Theses and Graduate Research

1995

\title{
Isolation and immunolocalization of unique epidermal proteins in leaves of Pisum sativum var. argenteum
}

Sunita Shah

San Jose State University

Follow this and additional works at: https://scholarworks.sjsu.edu/etd_theses

\section{Recommended Citation}

Shah, Sunita, "Isolation and immunolocalization of unique epidermal proteins in leaves of Pisum sativum var. argenteum" (1995). Master's Theses. 1031.

DOI: https://doi.org/10.31979/etd.yu73-qugb

https://scholarworks.sjsu.edu/etd_theses/1031

This Thesis is brought to you for free and open access by the Master's Theses and Graduate Research at SJSU ScholarWorks. It has been accepted for inclusion in Master's Theses by an authorized administrator of SJSU ScholarWorks. For more information, please contact scholarworks@sjsu.edu. 


\section{INFORMATION TO USERS}

This manuscript has been reproduced from the microfilm master. UMI films the text directly from the original or copy submitted. Thus, some thesis and dissertation copies are in typewriter face, while others may be from any type of computer printer.

The quality of this reproduction is dependent upon the quality of the copy submitted. Broken or indistinct print, colored or poor quality illustrations and photographs, print bleedthrough, substandard margins, and improper alignment can adversely affect reproduction.

In the unlikely. event that the author did not send UMI a complete manuscript and there are missing pages, these will be noted. Also, if unauthorized copyright material had to be removed, a note will indicate the deletion.

Oversize materials (e.g., maps, drawings, charts) are reproduced by sectioning the original, beginning at the upper left-hand corner and contimuing from left to right in equal sections with small overlaps. Each original is aiso photographed in one exposure and is included in reduced form at the back of the book.

Photographs included in the original manuscript have been reproduced serographically in this copy. Higher quality $6^{\prime \prime} \times 9^{n}$ black and white photographic prints are available for any photographs or illustrations appearing in this copy for an additional charge. Contact UMI directly to order.

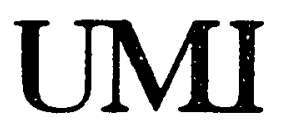

A Bell \& Howell Information Company 300 North Zeeb Road. Ann Afbor. MI 48106-1346 USA $313: 761-4700 \quad 800: 521-0600$ 
$-$ 
ISOLATION AND IMMUNOLOCALIZATION OF UNIQUE EPIDERMAL PROTEINS IN LEAVES OF PISUM SATIVUM VAR. ARGENTEUM

\author{
A Thesis \\ Presented to \\ The Faculty of the Department of Biological Sciences \\ San Jose State University \\ In Partial Fulfillment \\ of the Requirements for the Degree \\ Master of Science
}

by

Sunita Shah

May 1995 
UMI Number : 1374622

UMI Microform 1374622

Copyright 1995, by UMI Company. All rights reserved.

This microform edition is protected against unauthorized copying under Title 17, United States Code.

\section{UMI}

300 North Zeeb Road

Ann Arbor, MI 48103 
(C) 1995

Sunita Shah

ALL RIGHTS RESERVED 
APPROVED FOR THE DEPARTMENT OF BIOLOGICAL SCIENCES

Hand K Buck

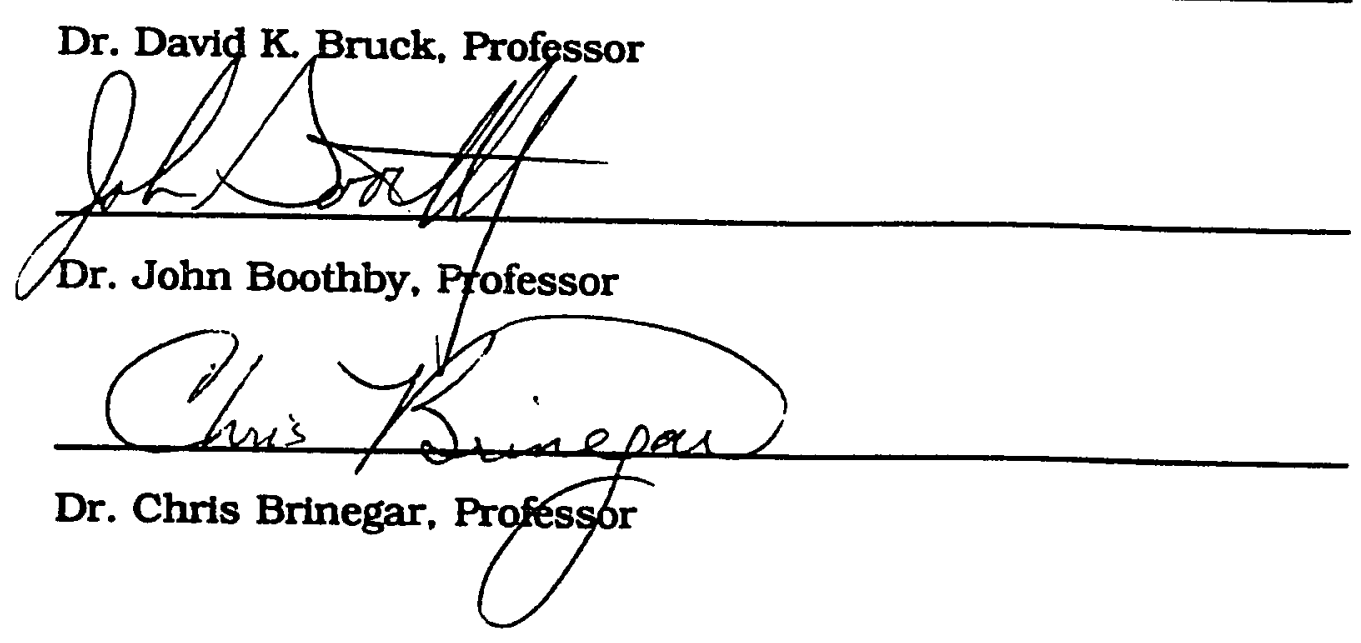

APPROVED FOR THE UNIVERSITY

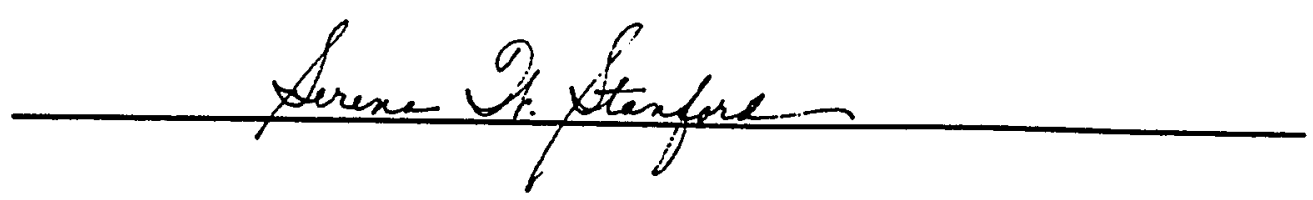




\begin{abstract}
ISOLATION AND IMMUNOLOCALIZATION OF UNIQUE EPIDERMAL PROTEINS IN LEAVES OF PISUM SATIVUM VAR. ARGENTEUM

By Sunita Shah
\end{abstract}

In this study, our goal was to isolate and localize unique proteins expressed in the mature epidermis of Pisum sativum var. argenteum. Three potential epidermal-specific proteins (ESPs) were Identified by analytical SDS-PAGE. One of these ESPs was isolated from preparative SDS-PAGE gels and used for polyclonal antibody production. Contradictory results were obtained regarding antibody specificity in immunoblots versus immunohistological sections. The anti-ESP antibodies reacted nonspecifically with all the major proteins of the epidermis on an immunoblot. Localization of fluorescently (AMCA)tagged anti-ESP antibodies on sections of mature leaves occurred almost exclusively in the epidermis, lending support to the unique, tissue-specific expression of this protein. 


\section{ACKNOWLEDGEMENTS}

I am grateful to Dr. David K. Bruck, who accepted me as his graduate student. I appreciate especially the weekends Dr. Bruck sacrificed for editing my thesis and his assistance in photography. His optimism and enthusiasm were a source of inspiration for me. Even during his sabbatical leave, Dr. John Boothby was always avallable to help me with the project. He willingly took my late night calls even at home. I appreciate the time and energy that both of them dedicated to help me design and complete this project. I am very grateful to Dr. Boothby for introducing me to Dr. Bruck. Many thanks to Dr. Chris Brinegar, who always had the time to answer my so-called "quick questions." I thank all my committee members for their hours of advice and support throughout the project.

My thanks to Carol Selter, Linda Goff, Wafa Neikro, Patricia Baty, Janet Piper, Wayne Parent, and Jim Yokota for their help during the investigation and preparation of this thesis. Special thanks to Mary $\mathrm{K}$. Wilson, who showed me the ins and outs of the lab when I first joined it, including her pea planting method, and various other useful tips. Her friendship means a lot to me. I would like to thank Rick Giberson at Ted Pella, Inc. for advice with the immunocytochemistry procedure.

I would like to express my gratitude to my family, who has helped me more than they know. Without their love, support and encouragement, I would not be where I am today. 
This work was supported by a San Jose State University Foundation development grant and student stipend award as well as a College of Science pair grant. 
TABLE OF CONTENTS

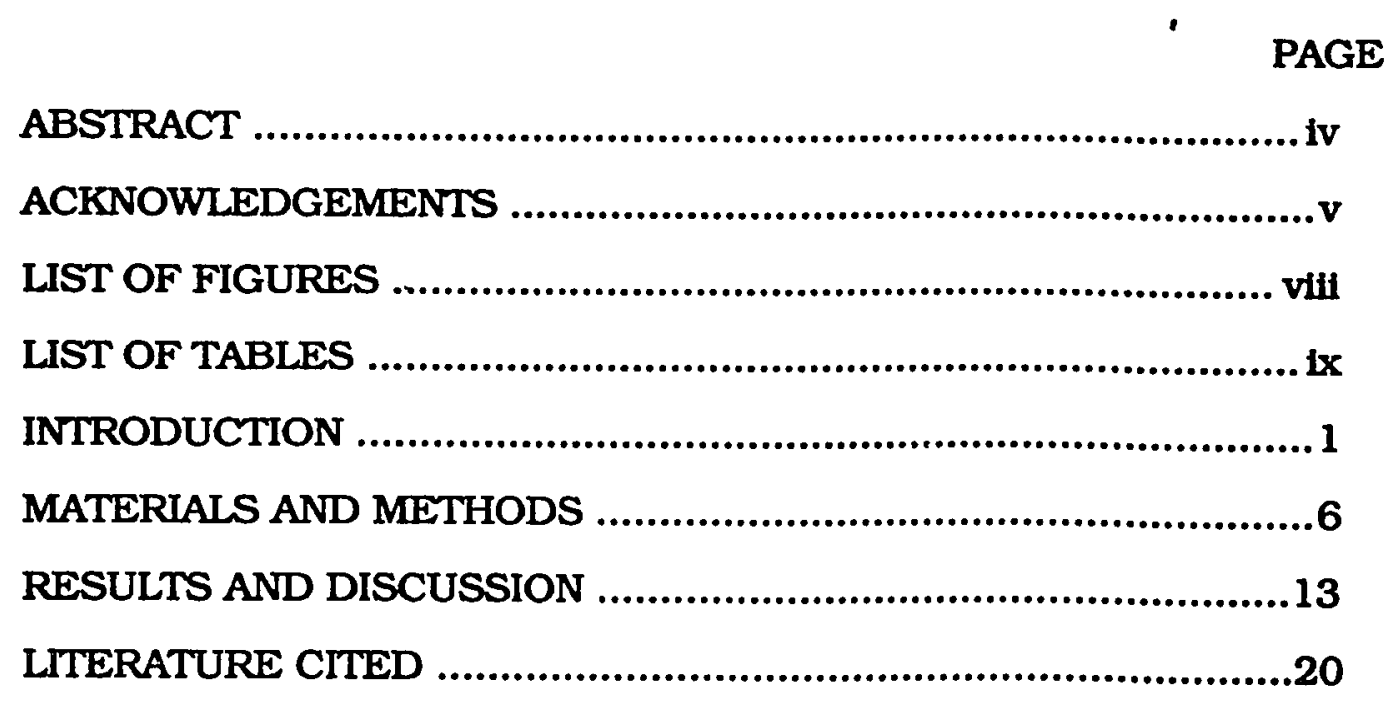




\section{LIST OF FIGURES}

PAGE

Figure 1. Photograph of 4-week-old specimen of Pisum sativum var. argenteum 23

Figure 2. Epidermal peel ..................................................... 24

Figure 3. Silver-stained SDS-PAGE protein profiles of epidermal and mesophyll extracts of leaves of arg

Figure 4. Protein content of fractions of rabbit anti-WMEx eluted from a Protein-A column 26

Figure 5. SDS-PAGE of silver-stained proteins from epidermis and mesophyll of leaves of arg prepared from Affinity Run No. 1 28

Figure 6. SDS-PAGE of silver-stained proteins from epidermis and mesophyll of leaves of arg prepared from Affinity Run No. 2

Figure 7. Immunoblot of anti-WEEx antibodies against different dilutions of WEEx and WMEx

Figure 8. Immunoblots of rabbit sera against ESP ...................... 32

Figure 9. Transverse section of mature arg leaf ............................. 33

Figure 10. Immunofluorescence micrographs of transverse section of arg leaves 


\section{IST OF TABLES}

PAGE

Table 1. Concentration of WEEx adsorptions onto Affi-Gel

10 gel coupled with anti-WMEx antibodies .................. 27

Table 2. Absorbance values of different rabbit antisera at different dilutions against WMEx, and WEEx .... 30 


\section{INTRODUCTION}

Cell differentiation presumably results from repression and derepression of specific genes, where the stages of differentiation are controlled by the appearance of specific gene products. It is. therefore, of interest to determine the timing of formation and identity of these gene products to understand the mechanism of cell differentiation. To isolate individual gene products, one must gain access to a purified cell type or tissue. The superficial location of the epidermis in plants makes it a suitable and accessible tissue for these manipulations. The epidermis of Pisum sativum var. argenteum (arg) was used in this investigation of epidermal-specific proteins, because this variety bears a single gene mutation (Marx 1978; Hoch et al 1980) causing the epidermis to be loosely attached to underlying mesophyll tissue and therefore easy to peel and isolate from other plant tissues. Thus pure preparations of epidermal tissue could be readily obtained.

Evidence has been accumulated that the epidermis is the fundamental cell type in plants (Bruck and Walker 1985a, 1985b). It is the first morphologically recognizable tissue (as protoderm) formed in the embryo. Epidermal tissue has many unique structural and functional characteristics (Bruck and Walker 1985a, b; 1986; Bruck et al 1989; Esau 1977; Walker and Bruck 1985) that are useful for identifying it at maturity and during development. The cells are structurally distinctive from other cell types by the presence of a cuticle (Bruck and Walker 1985a). Functionally, epidermal cells. 
unlike other parenchymatous cells, have a limited ability to dedifferentiate and redifferentiate (Walker 1983; Moore 1984; Walker and Bruck 1985), as indicated by their failure to participate in graft unions (Bruck and Walker 1986; Bruck et al 1989; Walker and Bruck 1985) or to regenerate after wounding (Bruck and Walker 1985b). At an early point in their differentiation, they become restricted to an anticlinal plane of cell division (Stewart and Burk 1970; Bruck and Walker 1985a), unless part of a multiple epidermis. These properties suggest the presence of some unique proteins responsible for these characteristics. Hence the arg epidermis was used to investigate the presence of unique tissue-specific proteins.

Similar to the procedure followed in the present investigation. tissue-specific proteins have been identified in Washingtonia flifera (Chandra Sekhar and DeMason 1988) and Cocos nucifera (DeMason and Chandra Sekhar 1990) by SDS-PAGE. Endosperm-storage proteins extracted from coconuts were separated by SDS-PAGE, isoelectric focusing, and two-dimensional gel electrophoresis. Individual bands were electroeluted and injected into hens to raise polyclonal antibodies. Antibody specificity was confirmed by an immunoblot analysis, and immunolocalization was performed by a silver-enhanced, immunogold technique. Two unique (tissue-specific) proteins were found in the crystalloids and a third in the protein matrix. In our investigation, tissue-specific proteins were isolated from epidermal protein extracts by SDS-PAGE and used for polyclonal antibody production. The antibodies, tagged with fluorescent markers 
(AMCA-labeled secondary antibodies), were used to confirm the uniqueness of these antigenic proteins.

Epidermal-specific proteins have been identified in other plants, such as maize (Sossountzov et al 1991) and Pachyphytum (Clark et al 1992). In maize, expression of lipid transfer protein (LTP) gene has been characterized. LTP gene expression was observed to be high in embryos and endosperm during seed maturation. The cotyledons, epicotyl, and root-hypocotyl axis of the embryo, and the embryonic and seedling coleoptile had high LTP mRNA levels, as observed by in situ hybridization. The outer epidermis of coleoptiles and leaves had the highest concentrations of immunogold-labeled LTP. In Pachyphytum, pure epidermal tissue was collected due to an underlying layer of thick-walled sclerenchyma cells from which the epidermis readily separated during peeling. Epidermal-specific transcripts were obtained by differential screening of a cDNA library and were found to be highly expressed in epidermal cells of developing stems and leaves. They were also expressed in the outer tunica layer of the shoot apical meristem, supporting the contention of Bruck and Walker (1985a) that the superficial cells of the meristem are epidermal in nature. The nucleotide sequence of these epidermalspecific transcripts (Clark and Bohnert 1993) has also been determined.

Another epidermal-specific protein, extracellular protein 2 (EP2), has been identified in carrot (Sterk et al 1991) by in situ hybridization of mRNA with antisense RNA. EP2 was isolated by means of antibodies 
raised against the proteins secreted into the medium surrounding an embryo. The EP2 gene is expressed exclusively in the protodermal cells of globular and heart-shaped somatic embryos. A gradual decrease in EP2 gene expression was observed in the protoderm as embryogenesis proceeded to the torpedo stage. It ceased in mature embryogenic tissues, but continued in the outer tunica layer of the shoot apical meristem and its recent derivatives in the seedling. The EP2 gene is transiently expressed and thus is stage specific as well as tissue specific.

In the present research, screening of epidermal-specific proteins was performed at the protein level rather than the mRNA level as in the investigations of Sossountzov et al (1991), Clark et al (1992), and Sterk et al (1991). Our goal was to identify unique proteins expressed in the mature epidermis for later use in studies of epidermal development during embryogenesis. Cell differentiation and anatomical pattern formation are significant events in plant embryo and adult development. Little is known about the mechanisms leading to cell differentiation in plants at the molecular level. Until recently, only genes for abundant seed proteins had been analyzed for tissuespecific and stage-specific gene expression (Perez-Grau and Goldberg 1989). Now, about 100 embryo-specific proteins have been identified (Goldberg et al 1989).

Most of our knowledge about differentiation in plants is at the morphological level. The cells of the youngest (early globular stage) proembryo appear morphologically identical (Bruck and Walker 
1985a). The onset of uniquely epidermal morphological features, beyond the secretion of cutin, of the exterior cells of the embryo occurs at different stages in different species. Yet the exterior cells of the youngest embryo, and the zygote itself, secrete a cuticle (Bruck and Walker 1985a), a feature generally considered to be distinctive to the epidermal cell type. Further evidence is required to verify whether these external cells, including the zygote, have become committed to development as, and so determined as, epidermal cells.

We hope to use unique epidermal proteins, identified to some degree in this project, to detect epidermal differentiation at stages prior to the appearance of distinctive morphological differences between embryonic cells. Antibodies raised against these unique proteins will be used as probes to determine the point at which embryonic cells initiate the expression of the proteins. The proteins, therefore, constitute molecular markers of epidermal identity and finer indicators than morphological criteria of a commitment to an epidermal cell type. By this method, the concept of the cell type may be more strictly and precisely defined. This kind of study is fundamental to the ultimate goal of understanding how all cells differentiate and how plants develop at the molecular level. 


\section{materIaIS AND METHODS}

Plant Growing Conditions. Seeds of arg variety of the garden pea (Pisum sativum var. argenteum) were sown in 5-inch plastic pots containing Supersoil (Rod McLellan Co., S. San Francisco, CA) plus Nutricote Total fertilizer (N-P-K 13-13-13; McCalif Growers' Supply. Ceres, CA). Seedlings were grown in a growth chamber with incandescent and fluorescent lllumination (ca. 2000 lux at plant level) provided over a $16 \mathrm{~h}$ photoperiod. Temperature was maintained at $21^{\circ} \mathrm{C}$ during the day and $13.5^{\circ} \mathrm{C}$ at night.

Extract Preparation. Epidermal and mesophyll tissues were collected from 2-to-4-week-old seedling leaves removed from the stem. The epidermis was peeled from both leaf surfaces with jeweler's forceps. The remaining internal tissue is referred to herein as mesophyll tissue despite also containing vascular tissues. The peeled epidermal and mesophyll tissues were frozen separately in liquid nitrogen and stored at $-20^{\circ} \mathrm{C}$. Whole epidermal extracts (WEEx) and whole mesophyil extracts (WMEx) were prepared by homogenizing the tissues in a $1.5 \mathrm{ml}$ microcentrifuge tube with a

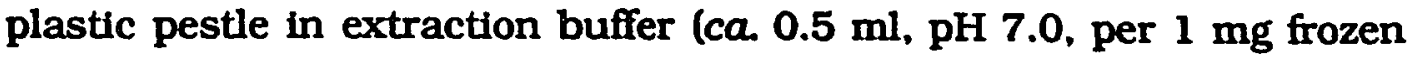
tissue) on ice. The extraction buffer consisted of $50 \mathrm{mM}$ Tris-HCl, $\mathrm{pH}$ 7.5, $5 \mathrm{mM}$ 2-mercaptoethanol, and $100 \mathrm{mM} \mathrm{NaCl}$, plus a protease inhibitor cocktail of $5 \mathrm{mM} \varepsilon$-amino- $n$-caproic acid, $1 \mathrm{mM}$ benzamidine, and $1 \mathrm{mM}$ phenylmethylsulfonyl fluoride. The homogenates were 
centrifuged at $10,000 \times \mathrm{g}$ for $15 \mathrm{~min}$ at $22^{\circ} \mathrm{C}$, and the supernatant was concentrated in Centricon 10 (Amicon, Danvers, MA)

microconcentrators in a Sorvall superspeed RC2-B centrifuge at 5000 $x g$ for $6 \mathrm{~h}$ at $4^{\circ} \mathrm{C}$. The concentrated protein extracts were stored at $-80^{\circ} \mathrm{C}$. $n$-Butanol was added to the protein extract in a $1: 1$ (vol/vol) ratio to eliminate lipids that might interfere during electrophoresis; the top butanol solution was pipetted off the remaining protein solution. The total content of soluble protein for WEEx and WMEx was determined by a Bradford protein assay using bovine serum albumin (BSA) as a standard (Bradford 1976).

Gel Electrophoresis. WEEx and WMEx (0.2 $\mathrm{mg}$ each) were separated by SDS-PAGE (Laemmli 1970). Analytical SDS-PAGE was performed using a $10 \%$ acrylamide (30\% acrylamide/0.8\% bisacrylamide) resolving gel and a 5\% stacking gel. Gels measuring 15 $\times 20 \times 0.15 \mathrm{~cm}$ were run at $30 \mathrm{~mA}$ for $4 \mathrm{~h}$. Gels were stained first with Coomassie Blue R-250 in 50\% methanol for $1 \mathrm{~h}$, destained with $50 \%$ methanol and $10 \%$ acetic acid overnight and then with $5 \%$ methanol and $7 \%$ acetic acid for 1-2 h. After Coomassie staining, gels were silver stained (Merril et al 1981) to detect the presence of minute amounts of protein on the gel. The protein bands from WEEx were compared with the bands from WMEx to detect the presence of unique proteins in the epidermal extract. The molecular weights of these bands were estimated by reference to molecular weight markers (Sigma. St. Louis, MO) at 205, 116, 97, 66, 45, and $29 \mathrm{kD}$. 
Preparation of Epidermal-Specific Proteins. Epidermal-specific proteins (ESP = ESPs) were prepared by two methods.

(1) Immunoaffinity Adsorption. Rabbit antibodies $(0.5 \mathrm{ml})$ against WEEx and WMEx (see below) were purified on a $5 \mathrm{ml}$ Protein Acyanogen bromide-activated column (Sigma, St. Louis, MO) and concentrated by ammonium sulfate (50\%) precipitation. The precipitate was analyzed for the presence and purity of antibodies on a $10 \%$ acrylamide, $8 \times 5 \times 0.15 \mathrm{~cm}$, SDS-PAGE gel. The gel was run for $2 \mathrm{~h}$ at $20 \mathrm{~mA}$. Molecular weight markers (Sigma, St. Louis, MO) used were 66, 45, 36, 29, 24, 20 and $14 \mathrm{kD}$. The purified anti-WMEx and anti-WEEx antibodies were run through a PD-10 sephadex column (Bio-Rad, Hercules, CA) to remove the ammonium ions from the precipitate. An activated immunoaffinity support of $1 \mathrm{ml}$ Affi-Gel 10 gel (Bio-Rad, Hercules, CA) was coupled with $3 \mathrm{ml}$ purified anti-WMEx antibodies $(0.5 \mathrm{mg} / \mathrm{ml})$. Additional sites on the gel were blocked with $1 \mathrm{M}$ ethanolamine- $\mathrm{HCl}, \mathrm{pH}$ 8.0, for $1 \mathrm{~h}$ and then washed with distilled water. Three times at $3 \mathrm{~h}$ intervals, $1 \mathrm{ml} \mathrm{WEEx}$ was added to $300 \mu \mathrm{l}$ of the gel adsorbed with anti-WMEx antibodies in a batch process in microfuge tubes at $4^{\circ} \mathrm{C}$, with agitation every half hour. WEEx was treated in this manner to remove all the proteins that were present in both epidermis and the mesophyll (common proteins). This batch process made possible the isolation of proteins present only in the epidermis (unique proteins). The WEEx components, unbound and bound to the anti-WMEx antibodies that were coupled to the Affi-Gel 
10 and WEEx were centrifuged at $10,000 \times g$ for $30 \mathrm{~s}$ at $22^{\circ} \mathrm{C}$. The supernatant containing the unique epidermal proteins, referred to as unbound proteins, was collected. Common proteins, which were adsorbed onto the anti-WMEx antibodies and referred to as bound proteins, were eluted off of the gel with $100 \mathrm{mM}$ glycine, pH 3.0. The bound and unbound proteins were analyzed on two $10 \%$ acrylamide, $15 \times 20 \times 0.15 \mathrm{~cm}$. SDS-PAGE gels. The gels were run at $30 \mathrm{~mA}$ for 4 h. Another gel was run as described above, except that a $12 \%$ acrylamide gel was used to analyze the lower molecular weight proteins.

(2) Preparative SDS-PAGE, WEEx $(0.5 \mathrm{mg})$ was run on two preparative, $12 \%$ acrylamide, $15 \times 20 \times 0.3 \mathrm{~cm}$, SDS-PAGE gels. From both gels, a narrow vertical slice containing separated WEEx proteins was excised, silver stained, and compared with the WMEx protein profile for the presence of unique bands. The bands on the unstained part of the gels corresponding in position to the unique band in the stained part of the gels was cut out and the slice stored at $-20^{\circ} \mathrm{C}$.

Preparation of Rabbit Antisera. Preimmune blood samples were collected from the ear vein of four 7-week-old female rabbits. The gel slice (see above), containing an ESP, was homogenized in an equal volume of $0.01 \mathrm{M}$ phosphate buffered saline (PBS), pH 7.2. Two rabbits were each subcutaneously injected with $1 \mathrm{ml}$ of the homogenate per shoulder. WEEx and WMEx $(1 \mathrm{ml}$ each of $0.5 \mathrm{mg} / \mathrm{ml}$ with Freund's complete adjuvant) were injected subcutaneously into 
each of two other rabbits. To all rabbits, a second booster dose was given after 4 weeks and a third booster dose after another 2 weeks. All the rabbits were bled 1 week after the third injection, and the blood was allowed to clot at room temperature for $1 \mathrm{~h}$. The supernatant was then centrifuged at $1000 \times \mathrm{g}$ for $15 \mathrm{~min}$, and the sera were collected and stored at $-20^{\circ} \mathrm{C}$.

Immunoblot. WEEx and WMEx were run on 12\% acrylamide, $8 \times 5$ $x 0.15 \mathrm{~cm}$. SDS-PAGE gels, and the bands were transferred onto $S \& S$ NYTRAN (Schleicher and Schuell, Keene, NH), a nitrocellulose membrane with $0.45 \mu \mathrm{m}$ diameter pores, in a Trans-Blot system (BioRad, Hercules, CA). Immunoblots (Harlow and Lane 1988) were prepared using preimmune serum, anti-WEEx, and ant1-ESP (all at 1:400 dilution) under identical conditions. An ELISA (Envall and Perlmann 1972) was also performed separately on preimmune serum. anti-WEEx, anti-WMEx, and anti-ESP using a goat anti-rabbit IgG/HRPO conjugate (Antibodies, Inc., Davis, CA) with $40 \mathrm{mM}$ ABTS as the substrate. All the above mentioned sera were tested against WEEx $(0.25 \mathrm{mg} / \mathrm{ml})$ and WMEx $(0.25 \mathrm{mg} / \mathrm{ml})$ individually at $405 \mathrm{~nm}$ with a $450 \mathrm{~nm}$ baseline correction.

Microtechnique. Mature leaves (the fourth, fifth, and sixth leaves produced by the seedling) of arg were cut into $1 \mathrm{~mm}^{2}$ segments and fixed in $4 \%$ paraformaldehyde and $0.5 \%$ glutaraldehyde in $0.05 \mathrm{M}$ sodium cacodylate buffer, $\mathrm{pH} \mathrm{6.8,} \mathrm{for} 2 \mathrm{~h}$ at room temperature. The 
segments were rinsed 3 times in the same buffer. The tissue segments were then partially dehydrated in a graded series of acetone solutions (25\%-95\%) for $5 \mathrm{~min}$ each. All the segments were inflitrated in the dark in the hydrophilic acrylic resin, LR White (Ted Pella, Inc., Redding, CA), for $1 \mathrm{~h}$. A second change of LR White was made for $12 \mathrm{~h}$ and a final change for $1 \mathrm{~h}$. This resin was used because it does not require total dehydration or excessive heating for polymerization and so maintains antigenicity better than most other resins. The resin was cured at $60^{\circ} \mathrm{C}$ for $16 \mathrm{~h}$. The tissue blocks were sectioned with a Sorvall JB-4 rotary microtome to obtain $1 \mu \mathrm{m}$ thick sections, which were affixed to glass slides on a hot plate at $42^{\circ} \mathrm{C}$ overnight. Tissue sections were stained with $1 \%$ crystal violet and photographed with Kodak TP 2415 film, or stained for immunocytochemistry (see below).

Immunocytochemistry. Tissue sections were treated with $1 \%$ nonfat dry milk in $10 \mathrm{mM}$ potassium phosphate buffer, $\mathrm{pH} 7.6$, for $2 \mathrm{~h}$ at $4^{\circ} \mathrm{C}$ to block non-specific sites. Dilutions at 1:10 of pre-immune, antiWEEx, anti-WMEx, and anti-ESP were used as primary antisera on different slides for $2 \mathrm{~h}$ at room temperature. The slides were first rinsed with $0.1 \%$ Tween-80 in $10 \mathrm{mM}$ potassium phosphate buffer, $\mathrm{pH}$ 7.6. for $10 \mathrm{~min}$ (4 changes) and then with indirect stream of running water for $15 \mathrm{~min}$. The slides were incubated with goat anti-rabbit IgG $(\mathrm{H}+\mathrm{L})$ conjugated to an AMCA fluorophore (ICN Biomedicals, Costa Mesa, CA) at a 1:75 dilution for $2 \mathrm{~h}$ at room temperature. After rinsing 
the slides, as described above, sections were viewed under epffluorescence optics on a Zeiss research microscope and photographed on Kodak Royal Gold 100 film. 


\section{RESULTS AND DISCUSSION}

Protein Extraction. The arg mutant of garden pea (Fig. 1) was used because the pectinaceous middle lamella that cements the epidermis to the underlying mesophyll is poorly formed. Thus it is easy to peel the epidermis from the mesophyll to obtain pure preparations of the tissues (Fig. 2). Epidermal cells are relatively thick-walled parenchyma cells, highly vacuolate with limited peripheral cytoplasm. Hence it was possible to extract only a limited quantity of protein from the cells. The average soluble protein content of several different extracts of epidermal and mesophyll tissues was low, less than 0.01 $\mathrm{mg} / \mathrm{ml}$ and about $0.1 \mathrm{mg} / \mathrm{ml}$, respectively. Consequently, the protein extracts were concentrated with microconcentrators to obtain more of the proteins, including the ones present in minute amounts. The average protein content after concentration was ca. $0.15 \mathrm{mg} / \mathrm{ml}$ (total $1.5 \mathrm{mg}$ ) in WEEx and $0.50 \mathrm{mg} / \mathrm{ml}$ (total $5 \mathrm{mg}$ ) in WMEx.

Protein Separation. A comparison of silver-stained protein bands (Fig. 3) of SDS-PAGE-separated WEEx and WMEx indicated a number of potential epidermal-specific protein bands. A higher number of unique proteins occurred in mesophyll extracts than in epidermal extracts. The majority of the bands were common to both tissues. Of the potential epidermal-specific bands, five were suitable candidates for isolation due to higher band intensity and greater separation from adjacent bands. 
Immunoaffinity Adsorption. The antibodies raised against WEEx and WMEx were purified on a Protein-A column and analyzed by SDSPAGE. The purification of an IgG fraction containing rabbit anti-WMEx antibodies by Protein-A column chromatography is shown in Fig. 4. Average sample concentration before chromatography was $600 \mu \mathrm{g}$. The concentration of bound antibodies was $125 \mu \mathrm{g}$ after elution at $\mathrm{pH}$ 3.0.

Purified anti-WMEx was coupled to Affi-Gel 10 gel for use in the elimination of proteins common to both epidermis and mesophyll from WEEx. Elimination of shared bands from the crowded electrophoretic profiles would make the unique proteins more accessible. Unique bands would then be eluted or excised and antibodies raised against them. However, only limited removal of shared proteins from WEEx was accomplished (Table 1). probably due to inefficient coupling of the antibodies to the Affi-Gel. The poor efficiency of coupling could be due to residual sites or to competition from contaminating proteins. In addition, our estimates of binding efficiency did not account for antibodies free in solution that were associated with but not bound to the beads. This omission would lead to erroneously high estimates of binding efficiency. Other reasons could be low levels of antibodies against high concentration proteins or absence of antibodies against some shared proteins. Nevertheless, three epidermal-specific bands, at molecular weights 40,21 , and 13 $k D$, were visible on gels loaded with the eluent from this procedure (Fig. 5 and 6). 
Preparative Gels. Preparative gels $(3 \mathrm{~mm}$ ) were run with a wide lane (10 $\mathrm{mm})$ and concentrated sample application to maximize the yield of unique proteins. In all three preparative $10 \%, 10 \%$, and $12 \%$ acrylamide SDS-PAGE gels, few bands were visible. Of the three bands identified as epidermal-specific proteins in Fig. 5 and 6, the $13 \mathrm{kD}$ band was faint but visible, having a concentration of only about 5 $\mathrm{ng} / \mathrm{ml}$, an approximation based on band intensity. The $12 \%$ acrylamide SDS-PAGE was successful in retarding migration of the 13 $\mathrm{kD}$ band, but the 40 and $21 \mathrm{kD}$ bands were absent in all of the preparative gels. The gels were stained for a longer period of time in an attempt to visualize the other two bands, but overstained gels resulted in poor resolution of any bands. The reason for the absence of these two bands on the gel, even after increasing the concentration of the epidermal extract, is unknown. The $13 \mathrm{kD}$ band (called hereafter the ESP) was faint but detectable in all of the preparative gels.

Antibody Reactivity and Specificity. An ELISA was conducted on all of the rabbit antisera collected to test for their reactivity at $\mathbf{4 0 5 / 4 5 0}$ nm against WEEx and WMEx (Table 2). The preimmune sera were more reactive with WEEx than with WMEx, undoubtedly as a result of non-specific binding. Anti-WEEx reacted with both WEEx and WMEx to about the same extent, an anticipated result given the commonality between the two tissues of the majority of the proteins. WMEx probably had a higher concentration of common proteins than WEEx. 
as the overall protein concentration in mesophyll was much higher than that in epidermal tissue and hence was equally reactive as WEEx. As expected, the rabbit anti-WMEx was more reactive to WMIEx than to WEEx.

Low but significant reactivity of anti-ESP was expected with WEEx because of the low proportion of ESPs in the whole epidermal extract. This pattern was in evidence with the anti-ESP collected from the blood sera of one rabbit (Rabbit No. 1). Surprisingly, however, the reactivity of anti-ESP from Rabbit No. 1 was less to WEEx than to WMEx. Negligible reactivity of anti-ESP with WMEx was expected, so that the relatively substantial degree of reactivity was probably a result of non-specific binding. Non-specific binding of the secondary antibody or the conjugate to the ELISA plates might have been prevented by blocking plates with BSA. The reactivity of anti-ESP from a second rabbit (Rabbit No. 2) was almost negligible with both WEEx and WMEx. The amount of ESP injected into each rabbit was very low, as it was electrophoretically obtained by excision from a preparative gel in a purified state. Therefore, only 10-15 ng was recovered per gel, perhaps an inadequate amount to elicit a significant immune response.

The reactivity of anti-WEEx antibodies toward both epidermis and mesophyll was confirmed by an immunoblot (Fig. 7). An immunoblot was also conducted on the preimmune and anti-ESP antibodies (Fig. 8). Like the ELISA absorbance values for reactivity, preimmune sera reacted with the molecular weight markers, WEEx, and WMEx non- 
specifically. The anti-ESP did not react with any molecular weight markers or WMEx bands. They were expected to react only with the unique $13 \mathrm{kD}$ protein band but instead reacted non-specifically with all WEEx bands. It is conceivable, although highly improbable, that the ESPs bore an epitope common to all WEEx proteins so that antibodies against it bound to a number of bands. More likely, the $13 \mathrm{kD}$ band consisted of a number of small subunits fragmented from the higher molecular weight proteins, as it was at the dye front in an extremely low molecular weight position. If so, when those fragments were injected into the rabbits as antigens, antibodies were produced against a great number of small subunits of the larger proteins. Thus these antibodies bound to many bands.

Immunocytochemistry. Transverse sections of arg leaves revealed a poorly defined, single-layered palisade mesophyll and an extensive spongy mesophyll interrupted by closely spaced veins (Fig. 9). Because the epidermal cells bear large central vacuoles, AMCA-specific (blue) fluorescence was observed only on the thin cytoplasmic periphery of the cells. As expected, little AMCA-specific fluorescence occurred on sections treated with preimmune antisera (Fig. 10a). The few spots observed lacked tissue and cell type specificity or occurred in the resin surrounding the sections, suggesting that this low-level binding of the secondary antibodies was random and non-specific. Similar results were obtained when control sections were treated with AMCAconjugated secondary antibodies only, without the primary antibodies. 
Chlorophyll (yellow) autofluorescence occurred throughout the mesophyll in all sections treated with either preimmune or immune sera. Anti-WEEx antibodies bound in about equal amount to the epidermis and spongy mesophyll (Fig. 10b), consistent with the abundance of protein shared by the two tissues. Anti-WMEx antibodies bound preferentially to internal tissues of the leaf, including spongy mesophyll, palisade mesophyil, and xylem parenchyma (Fig. 10c). Limited localization occurred in the epidermis as a result of the lower concentration of protein present in that tissue in comparison to internal tissues. Binding of anti-ESP antibodies was restricted to the epidermis (Fig. 10d). The label was nearly absent in internal tissues, although occasional non-specific binding was evident in the spongy mesophyll. These results are curious in light of the lack of specificity of the anti-ESP antibodies in the immunoblots discussed above.

The immunocytochemical investigation described above suggested the successful localization of a unique epidermal protein and. therefore, the isolation of antibodies specific to this determinant. However, this possibility was contradicted by the immunoblots, in which the anti-ESP antibodies recognized virtually all epidermal proteins, whether unique or shared. Further contradiction occurred with the reactivity of preimmune serum with proteins of both tissue extracts and molecular weight standards. Additional work is clearly necessary to confirm the localization of epidermal-specific proteins. This investigation has, nonetheless, identified several useful procedures for this purpose. Modifications of the present procedure 
might include greater concentration of the epidermal extract in the rabbit injections to elicit a stronger immune response. A more concentrated extract would allow an Affi-Gel column removal of common proteins, in which washings are more efficient, rather than reliance on the batch immunoadsorption process. Many of the detalls of the procedure for localizing tissue-specific proteins have been worked out in this research, providing a headstart for future studies. 


\section{LITERATURE CITED}

Bradford, M.M. 1976. A rapid and sensitive method for the quantitation of microgram quantities of protein utilizing the principle of protein-dye binding. Anal. Biochem. 72:248-254.

Bruck, D.K., and Walker, D.B. 1985a. Cell determination during embryogenesis in Citrus jambhirt. I. Ontogeny of the epidermis. Bot. Gaz (Chicago). 146:188-195.

Bruck, D.K., and Walker, D.B. 1985b. Cell determination during embryogenesis in Citrus jambhirL. II. Epidermal differentiation as a one-time event. Am. J. Bot. 72:1602-1609.

Bruck, D.K., and Walker, D.B. 1986. Cell determination during embryogenesis in Citrus jambhiri. III. Graft formation and nonformation in embryonic tissues. Can. J. Bot. 64:2057-2062.

Bruck, D.K., Alvarez, R.J., and Walker, D.B. 1989. Leaf grafting and its prevention by the intact and abraded epidermis. Can. J. Bot. 67:303-312.

Chandra Sekhar, K.N., and DeMason, D.A. 1988. A comparison of endosperm and embryo proteins of the palm, Washingtonia filfera. Am. J. Bot. 75:338-342.

Clark, A.M., Verbeke, J.A., and Bohnert, H.J. 1992. Epidermis-specific gene expression in Pachyphytum. Plant Cell 4:1189-1198.

Clark, A.M., and Bohnert, H.J. 1993. Epidermis-specific transcripts. Nucleotide sequence of a full-length CDNA of EP112, encoding a putative lipid transfer protein. Plant Physiol. 103:677-678.

DeMason, D.A., and Chandra Sekhar, K.N. 1990. Electrophoretic characterization and immunological localization of coconut (Cocos nucifera L.) endosperm-storage proteins. Bot. Gaz. 15:302-313.

Envall, E., and Perlmann, P. 1972. Enzyme-linked immunosorbent assay. III. Quantitation of specific antibodies by enzyme-labeled antiimmunoglobulin in antigen-coated tubes. J. Immunol. 109:129-135. 
Esau, K. 1977. Anatomy of Seed Plants. Wiley, New York.

Goldberg, R.B., Barker, S.J., and Perez-Grau, L. 1989. Regulation of gene expression during plant embryogenesis. Cell 56:149-160.

Goldberg, R.B., Paiva, G., and Yadegarl, R. 1994. Plant embryogenesis: zygote to seed. Science 266:605-614.

Harlow, E., and Lane, D. (eds). 1988. Antibodies: A Laboratory Manual. Coldspring Harbor Press, New York.

Hoch, H.C., Pratt, C., and Marx, G.A. 1980. Subepidermal air spaces: basis for the phenotypic expression of the Argenteum mutant of Pisum. Am. J. Bot. 67:905-911.

Laemmli, U.K. 1970. Cleavage of structural proteins during the assembly of the head of bacteriophage $T_{4}$. Nature 227:680-685.

Marx, G.A. 1978. Argenteum: a mutant under nuclear and extranuclear control. Pisum Newsletter 10:34-37.

Merril, C.R., Goldman, D., Sedman, S.A., and Ebert, M.H. 1981. Ultrasensitive stain for proteins in polyacrylamide gels shows regional variation in cerebrospinal fluid proteins. Science 211:1437-1438.

Moore, R. 1984. A model for graft compatibility-incompatibility in higher plants. Am. J. Bot. 71:752-758.

Perez-Grau, L., and Goldberg, R.B. 1989. Soybean seed protein genes are regulated spatially during embryogenesis. Piant Ceil 1:10951109.

Sossountzov, L., Ruiz-Avilla, L., Vignols, F., Arondel, V., Tchang, F., Grosbois, M., Guerbette, F., Miginiac, E., Delseny, M., Puigdomenech, P., and Kader, J.C. 1991. Spatial and temporal expression of a maize lipid transfer protein. Plant Cell 3:923-933.

Sterk, P., Booij, H., Schellekens, G.A., Van Kammen, A., and De Vries, S.C. 1991. Cell-specific expression of the carrot EP2 lipid transfer protein gene. Plant Cell 3:907-921. 
Stewart, R.N., and Burk, L.G. 1970. Independence of tissues derived from the apical layers in ontogeny of the tobacco leaf and ovary. Am. J. Bot. 45:517-525.

Walker; D.B. 1983. The response of epidermal cells. In Vegetative compatibility responses in plants, (Moore, R. ed), pp.123-137. Baylor University Press, Waco, Texas.

Walker, D.B., and Bruck, D.K. 1985. Incompetence of stem epidermal cells to dedifferentiate and graft. Can. J. Bot. 63:2129-2132. 


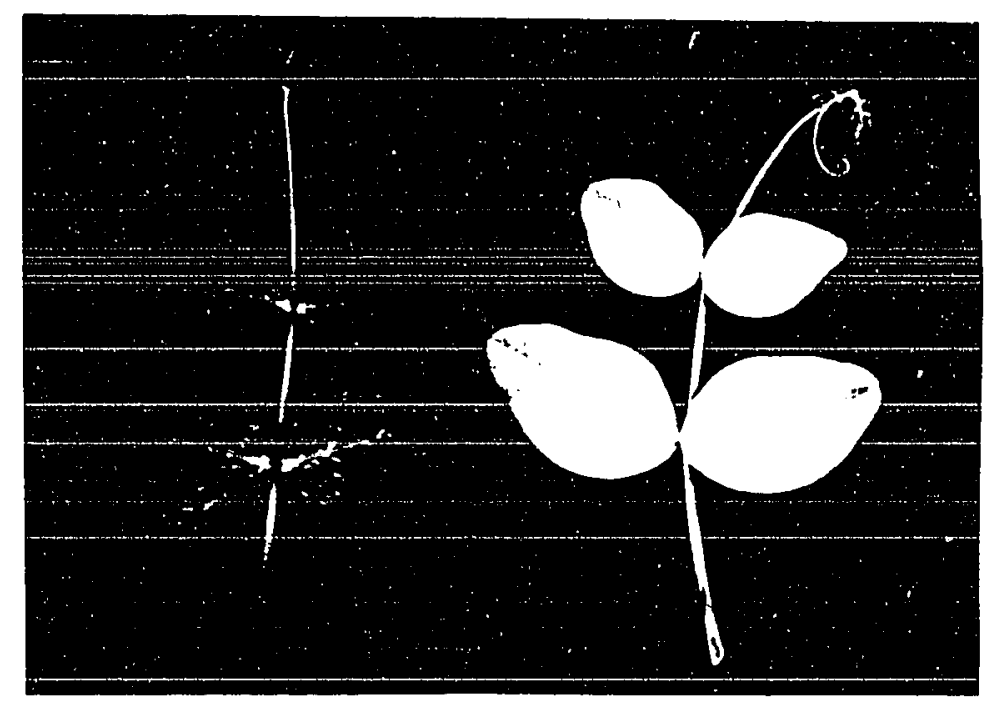

Figure 1. Photograph of 4-week-old leaves of the wildtype (left) and argenteum (right) varieties of Pisum sativum. Extensive intercellular air spaces occur between the epidermis and mesophyll or cortical tissue, resulting in a silver cast to the leaves and stems of the arg mutant. 


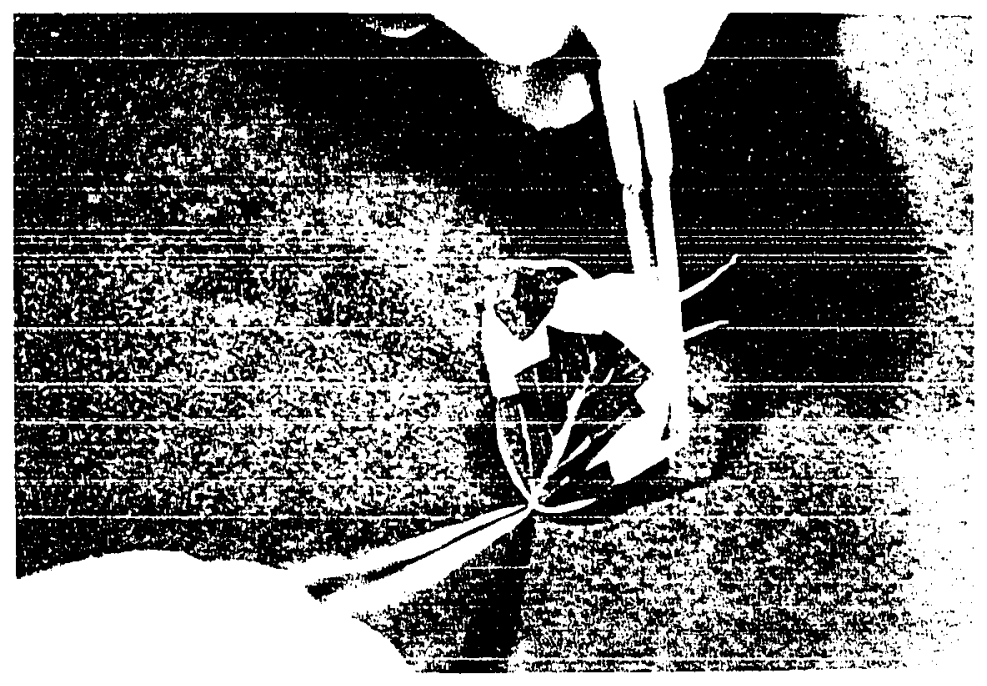

Figure 2. Peeling of the epidermis from the arg leaf mesophyll with jeweler's forceps. Pure preparations of epidermis and mesophyll are easily obtained due to the loose attachment of the epidermis and underlying mesophyll. 


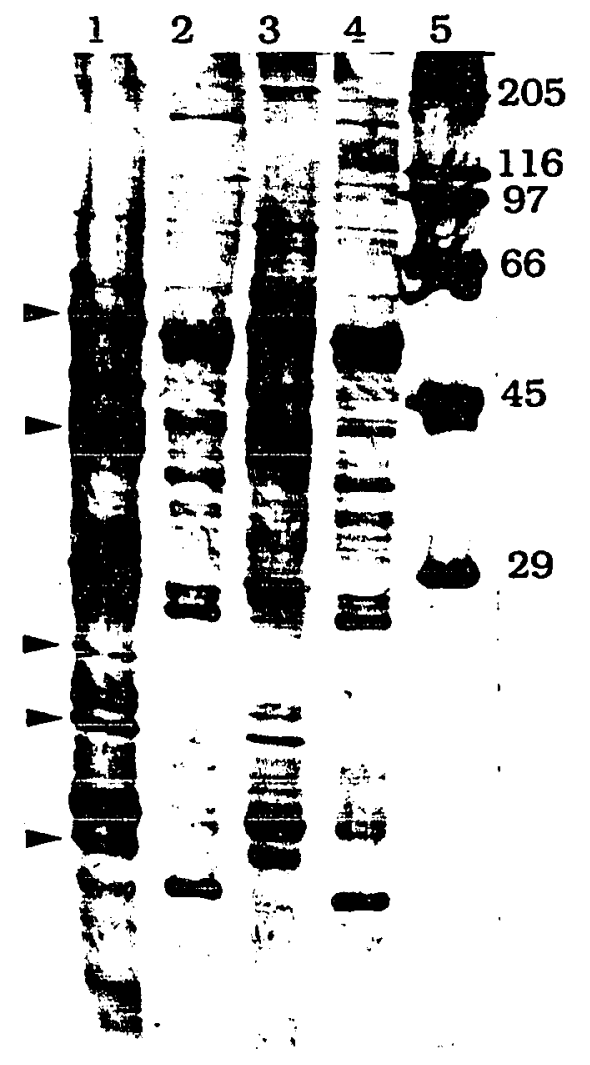

Figure 3. SDS-PAGE protein profiles of epidermal and mesophyll extracts of leaves of $P$. sativum var. argenteum resolved on a $10 \%$ acrylamide gel and silver stained. Lane 1: epidermal protein extract. Lane 2: mesophyll protein extract. Lane 3: two-fold diluted epidermal protein extract. Lane 4: two-fold diluted mesophyll protein extract. Lane 5: molecular weight markers (in $\mathrm{kD}$ ). The arrows point to potential epidermal-specific protein bands. 


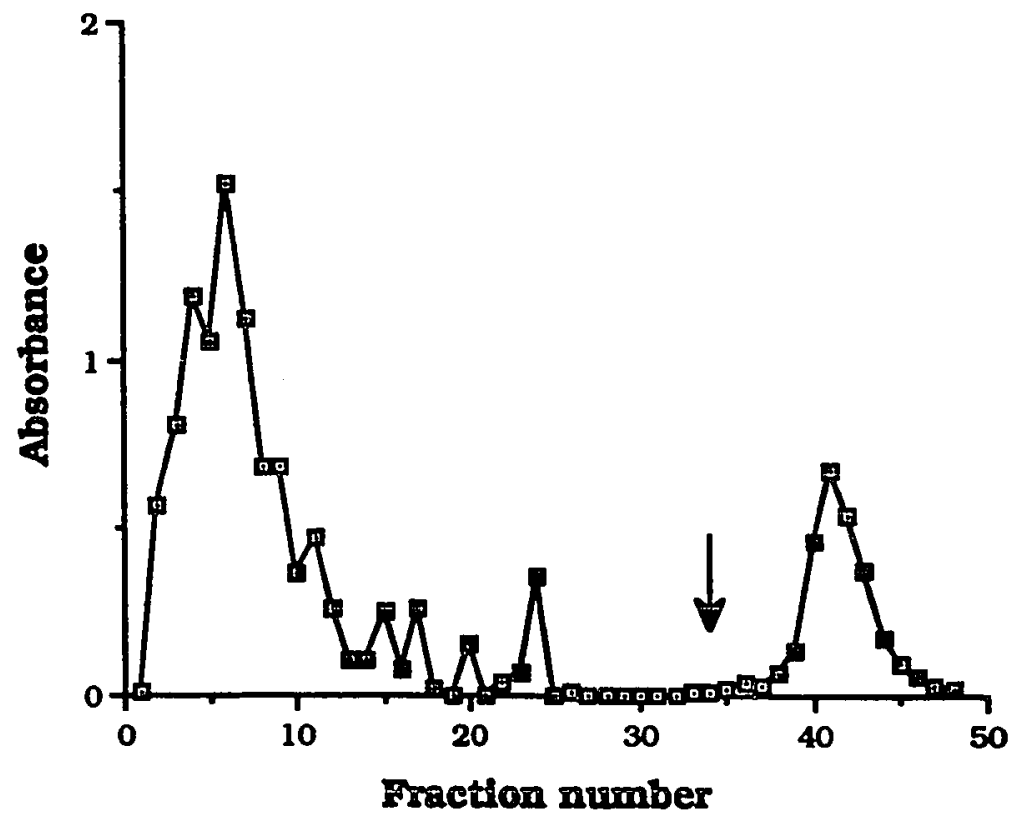

Figure 4. Protein content (Bradford assay), as measured by absorbance at $595 \mathrm{~nm}$, of fractions of rabbit ant1-WMEx eluted from a Protein-A column. Arrow indicates point of addition of elution buffer $(100 \mathrm{mM}$ glycine, $\mathrm{pH}$ 3.0). 
Table 1. Concentration of the WEEx adsorptions onto Affi-Gel 10 gel coupled with anti-WMEx antibodies. The percent efficiency refers to the degree of anti-WMEx bound to the Affi-Gel.

\begin{tabular}{|c|c|c|c|c|}
\hline $\begin{array}{c}\text { Affinity } \\
\text { Run }\end{array}$ & $\begin{array}{c}\text { Percent } \\
\text { Efficiency }\end{array}$ & $\begin{array}{c}\text { WEEx } \\
\text { (mg) }\end{array}$ & $\begin{array}{c}\text { Unbound Protein } \\
\text { (mg) }\end{array}$ & $\begin{array}{c}\text { Bound Protein } \\
\text { (mg) }\end{array}$ \\
\hline 1 & 30 & 0.16 & 0.12 & 0.004 \\
\hline 2 & 52 & 0.32 & 0.28 & 0.035 \\
\hline 3 & 52 & 0.20 & 0.16 & 0.020 \\
\hline
\end{tabular}




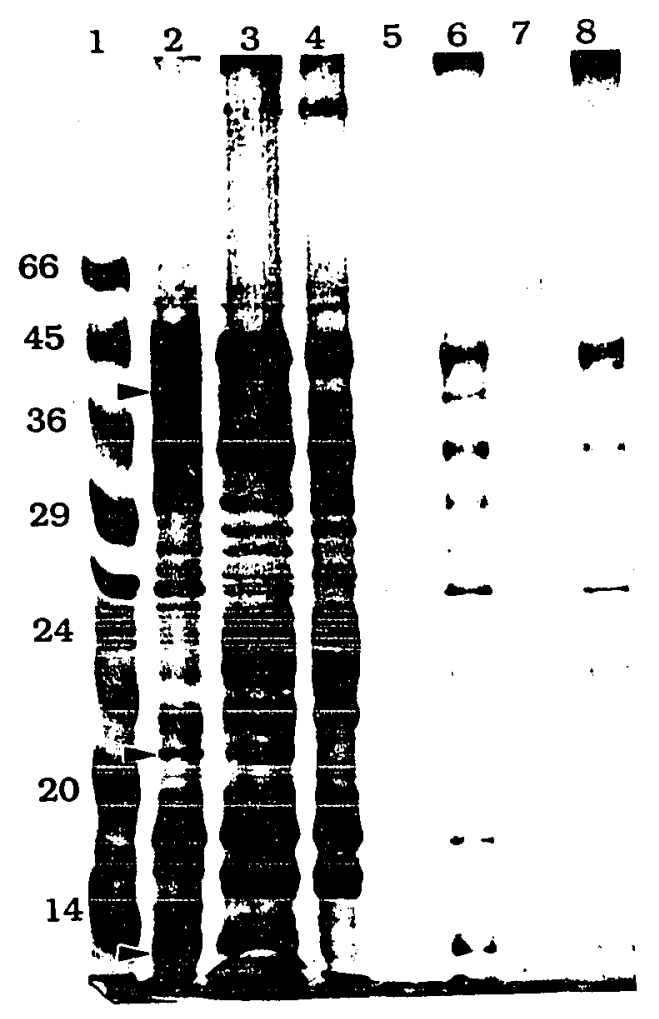

Figure 5. SDS-PAGE of silver-stained proteins from epidermis and mesophyll of leaves of $P$. sativum var. argenteum prepared from Affinity Run No. 1 and resolved on a 10\% acrylamide gel. Lane 1: molecular weight markers (in $\mathrm{kD}$ ). Lane 2: WEEx. Lane 3: mixture of WEEx and WMEx. Lane 4: WMEx. Lane 5: epidermal proteins adsorbed onto anti-mesophyll antibodies (referred to as "bound proteins I"). Lane 6: epidermal proteins that failed to adsorb onto anti-mesophyll antibodies (referred to as "unbound proteins I"). Lane 7: bound proteins II. Lane 8: unbound proteins II. Proteins designated by I and Il are products of sequential adsorbances on Affi-Gel. The arrows point to potential epidermal-specific protein bands. 


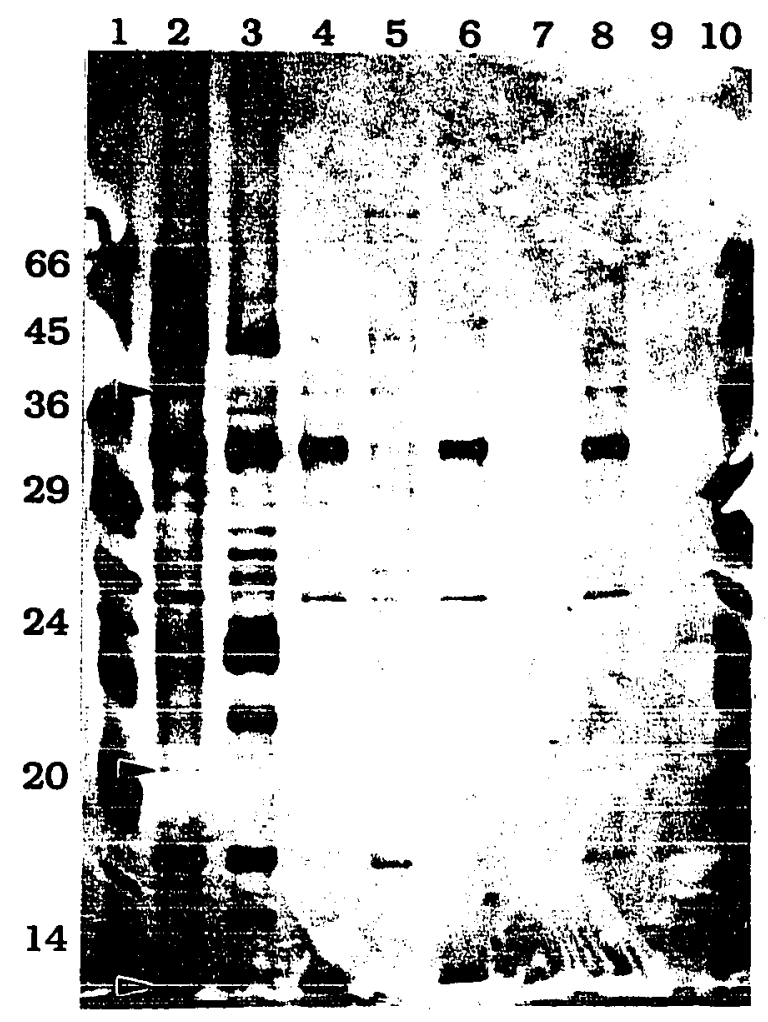

Figure 6. SDS-PAGE of silver-stained proteins from epidermis and mesophyll of leaves of $P$. satiwum var. argenteum prepared from Affinity Run No. 2 and resolved on a 10\% acrylamide gel. Lanes 1 and 10: molecular weight markers (in kD). Lane 2: WEEx. Lane 3: WMEx. Lane 4: unbound proteins I. Lane 5: bound proteins I. Lane 6: unbound proteins II. Lane 7: bound proteins II. Lane 8: unbound proteins III. Lane 9: bound proteins III. Proteins designated by I, II and III are products of sequential adsorbances on Affi-Gel. The arrows point to epidermal-specific protein bands. 
Table 2. Absorbance values of different rabbit antisera at different dilutions against whole mesophyll extract (WMEx) and whole epidermal extract (WEEx), as measured by ELISA at $405 \mathrm{~nm}$ with a $450 \mathrm{~nm}$ baseline correction.

\begin{tabular}{|c|c|c|c|c|c|c|c|}
\hline Antiserum & Antigen & \multicolumn{5}{|c|}{ Antiserum Dilutions } \\
\hline \hline & & $1: 100$ & $1: 200$ & $1: 400$ & $1: 800$ & $1: 1600$ & $1: 3200$ \\
\hline Preimmune & WEEx & 0.040 & 0.036 & 0.021 & 0.013 & 0.006 & 0.002 \\
\hline & WMEx & 0.027 & 0.016 & 0.014 & 0.008 & 0.005 & 0.004 \\
\hline Anti-WEEx & WEEx & 0.444 & 0.221 & 0.193 & 0.085 & 0.018 & 0.001 \\
\hline & WMEx & 0.460 & 0.367 & 0.256 & 0.176 & 0.106 & 0.069 \\
\hline Anti-WMEx & WEEx & 0.552 & 0.343 & 0.250 & 0.118 & 0.064 & 0.026 \\
\hline & WMEx & 0.995 & 0.791 & 0.554 & 0.305 & 0.144 & 0.064 \\
\hline Anti-ESP No. 1 & WEEx & 0.056 & 0.025 & 0.020 & 0.016 & 0.008 & 0.004 \\
\hline & WMEx & 0.064 & 0.041 & 0.033 & 0.018 & 0.009 & 0.003 \\
\hline Anti-ESP No. 2 & WEEx & 0.044 & 0.034 & 0.021 & 0.011 & 0.009 & 0.004 \\
\hline & WMEx & 0.020 & 0.011 & 0.008 & 0.004 & 0.002 & 0.001 \\
\hline
\end{tabular}




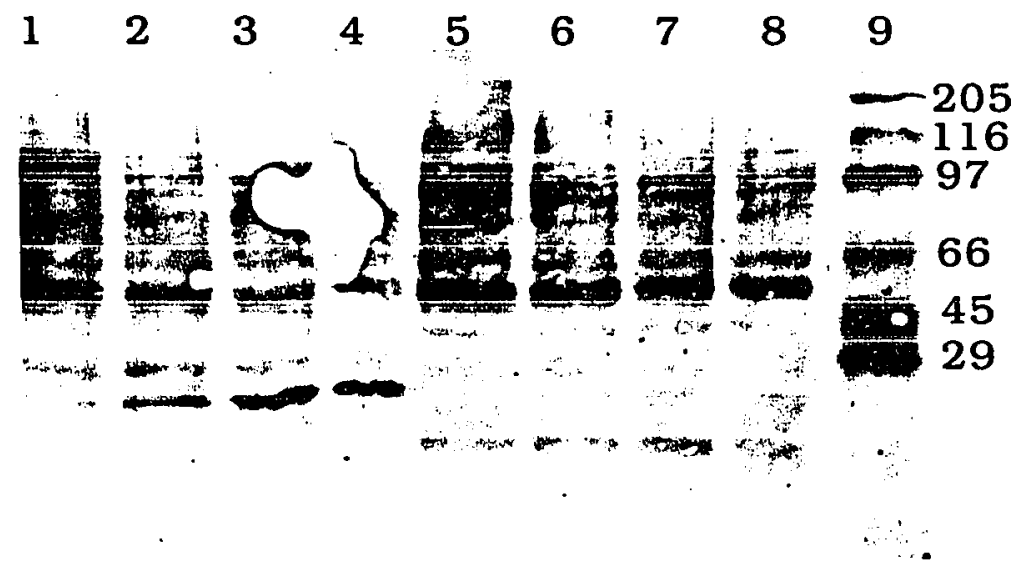

Figure 7. Immunoblot of anti-WEEx antibodies against different dilutions of WEEx and WMEx. Lane 1: WEEx. Lane 2: 2-fold diluted WEEx. Lane 3: 4-fold diluted WEEx. Lane 4: 8-fold diluted WEEx. Lane 5: WMEx. Lane 6: 2-fold diluted WMEx. Lane 7: 4-fold diluted WMEx. Lane 8. 8-fold diluted WMEx. Lane 9: prestained molecular weight markers (in $\mathrm{kD}$ ). 


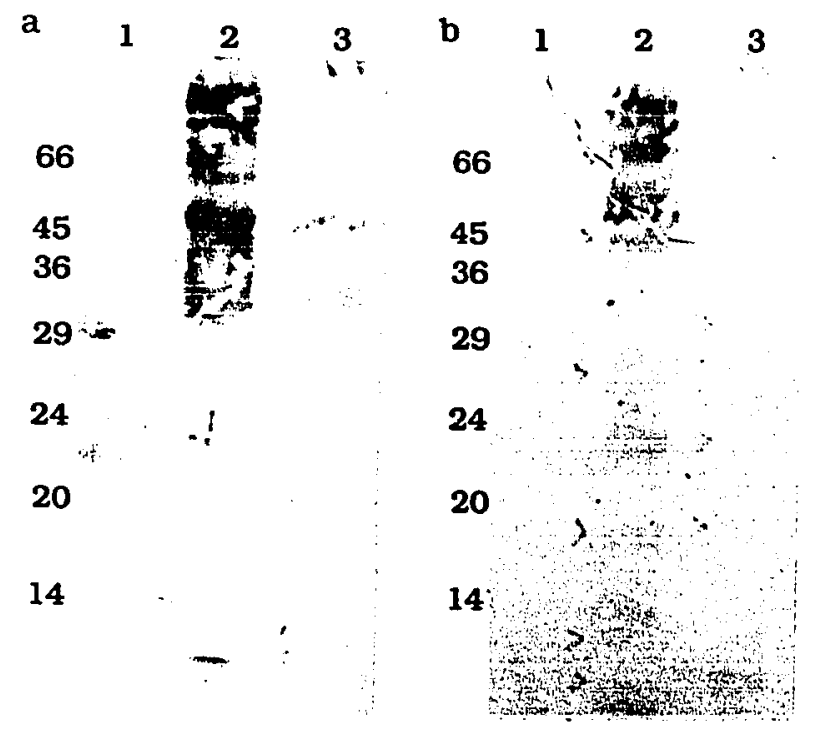

Figure 8. Immunoblots of rabbit sera against ESP. (a) Pre-immune and (b) immune (anti-ESP) sera. Both sera were diluted 1:400 in 1\% BSA in $50 \mathrm{mM}$ TBS, $\mathrm{pH}$ 7.2. Lane 1: molecular weight markers (in $\mathrm{kD}$ ).

Lane 2: epidermal protein extract. Lane 3: mesophyll protein extract. 


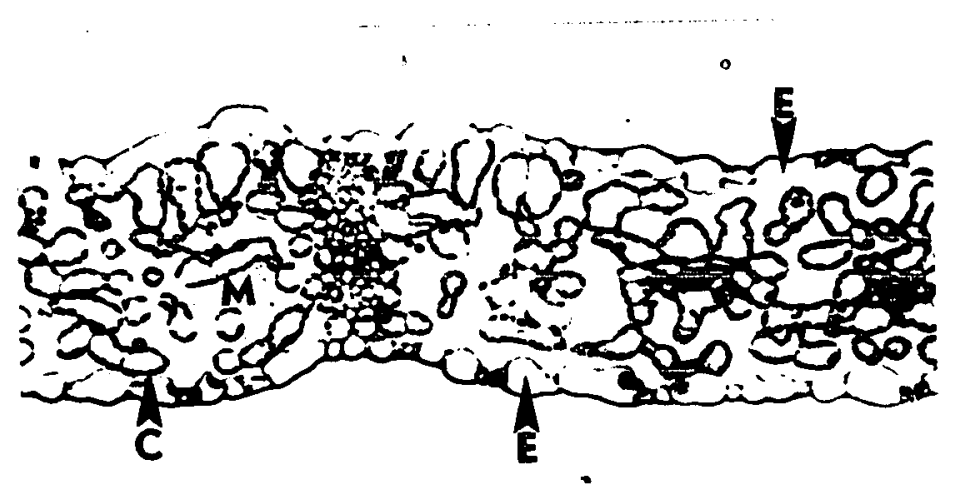

Figure 9. Transverse section of mature leaf of $P$. sativum var. argenteum. Palisade mesophyll is poorly defined, whereas spongy mesophyll $(M)$ is extensive. A vein is visible within the spongy mesophyll. Large chloroplasts $(C)$ are numerous in the mesophyll cells. The epidermal cells $(E)$ are highly vacuolate, and their walls are relatively thick, especially the outer tangential walls. 


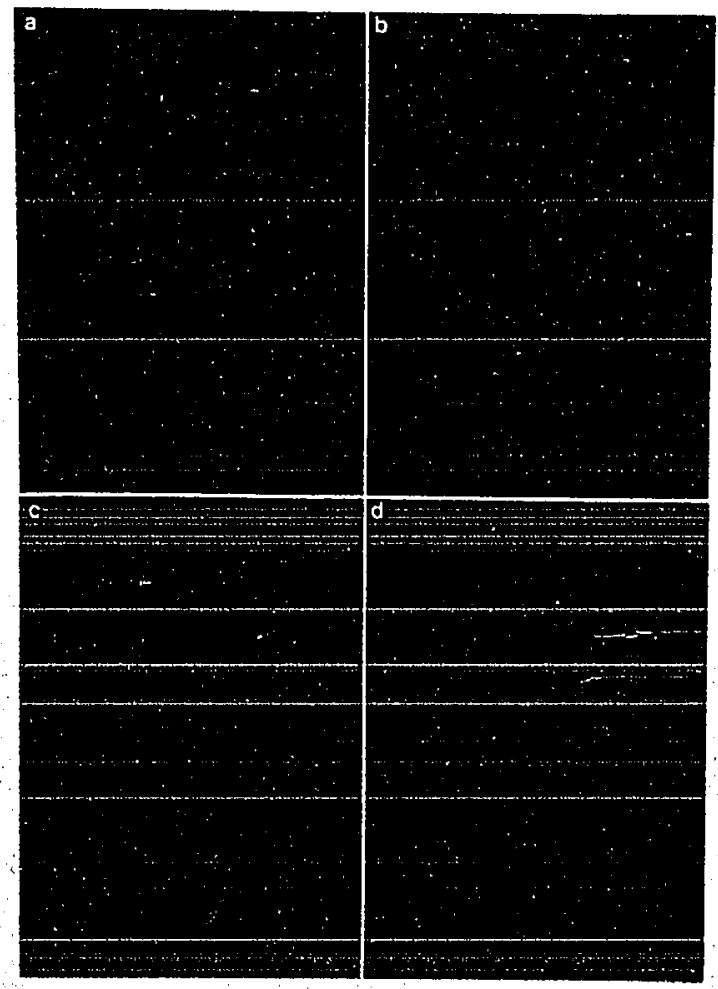

Figure 10. Immunofluorescence micrographs of transverse sections of leaves of $P$. sativum var. argenteum. (a) Application of preimmune rabbit antisera followed by goat anti-rabbit IgG-AMCA (blue fluorescing) conjugate. (b) Application of rabbit antibodies prepared against WEEx followed by goat anti-rabbit IgG-AMCA (blue fluorescing) conjugate. (c) Application of rabbit antibodies prepared against WMEx followed by goat anti-rabbit IgG-AMCA (blue fluorescing) conjugate. (d) Application of rabbit antibodies prepared against ESP followed by goat anti-rabbit IgG-AMCA (blue fluorescing) conjugate. Chlorophyll (yellow fluorescing) autofluorescence visible in chloroplasts of mesophyll of all sections. 